\title{
Effect of Age on Glucose Oxidation by Isolated Rat Islets
}

\author{
G. M. Reaven and P. D. Reaven \\ Department of Medicine, Stanford University School of Medicine and Geriatric Research, Education and Clinical Center, \\ Veterans Administration Medical Center, Palo Alto, California, USA
}

Summary. Islets were isolated from pancreases of 2-month and 12-month-old rats, and the oxidation of ${ }^{14} \mathrm{C}$-glucose to ${ }^{14} \mathrm{CO}_{2}$ determined at various medium D-glucose concentration. Islets from 12-month-old rats oxidized significantly less glucose than those from 2-month-old rats at glucose concentrations of 150,300 , and $450 \mathrm{mg} / \mathrm{dl}$, and this was true when islets were selected by hand or by Ficoll density gradient separation. The effect of age on glucose oxidation was seen when islets were incubated with [U$\left.{ }^{14} \mathrm{C}\right],\left[1-{ }^{14} \mathrm{C}\right]$, or $\left[6-{ }^{14} \mathrm{C}\right]$ glucose. The results raise the possibility that previously reported age-related defects in glucose-stimulated insulin secretion may be secondary to the effect of age on islet glucose catabolism.

Key words: Age, islet glucose metabolism, insulin secretion, glucose oxidation, glucose, isolated islets, insulin.

A recent study from our laboratory indicated that glucose-stimulated insulin release from isolated pancreatic islets decreased progressively as rats aged from 2 to 18 months of age [1]. To gain insight into the mechanism of this age-related effect, we have compared glucose oxidation by islets isolated from rats 2 and 12 months old.

\section{Materials and Methods}

\section{Animals}

Male Sprague-Dawley rats (Charles Rivers Co., Boston, Mass.) 2 and 12 months of age were used. The rats were fed standard laboratory chow (Wayne Lab Blox, Allied Mills, Chicago, Ill.) ad libitum, and maintained on a $12 \mathrm{~h}$ light/dark $(0600 \mathrm{~h} / 1800 \mathrm{~h})$ cycle. Food was removed at $0830 \mathrm{~h}$ and experiments begun at $1230 \mathrm{~h}$.

\section{Preparation of Pancreatic Islets}

Three 2-month-old or two 12-month-old rats were used for each islet preparation. Islets were isolated by minor modifications of the collagenase-digestion method of Lacy and Kostianovsky [2]. Following the initial selection of islets with the aid of a dissecting microscope, an attempt was made to hand-pick islets which were free of acinar tissue by several transfers to Petri dishes containing fresh Hanks' solution. In other experiments, islets were separated following collagenase digestion by Ficoll density gradient centrifugation at $22^{\circ} \mathrm{C}$.

\section{Glucose Oxidation}

Glucose oxidation by batches of 30 islets was carried out with only minor modifications of previously described methods [3, 4]. Islets were incubated at glucose concentrations of 50, 150, 300 and $450 \mathrm{mg} / \mathrm{dl}$ for $60 \mathrm{~min}$. Radiolabelled glucose was added in the form of either $\left[\mathrm{U}-{ }^{14} \mathrm{C}\right],\left[1-{ }^{14} \mathrm{C}\right]$, or $\left[6{ }^{-14} \mathrm{C}\right]$. The amount of ${ }^{14} \mathrm{CO}_{2}$ formed was determined by liquid scintillation counting, and results expressed as pmoles of glucose equivalents oxidized by ten islets in $60 \mathrm{~min}$. Two-tailed Students" t-test was used for statistical evaluation.

\section{Results}

The results seen following incubation with $\left[\mathrm{U}-{ }^{14} \mathrm{C}\right]$ glucose are seen in Figs. 1 and 2, and indicate that hand-picked (Fig. 1) or Ficoll-isolated (Fig. 2) islets from 12-month-old rats converted significantly less glucose to $\mathrm{CO}_{2}$ than did islets from 2-month-old rats at each incubation medium glucose concentration above $50 \mathrm{mg} / \mathrm{dl}$. The total amount of glucose converted to $\mathrm{CO}_{2}$ by Ficoll-isolated islets was less than when the islets were hand-picked.

The results of incubating islets with either $\left[6-{ }^{14} \mathrm{C}\right]$ or $\left[1-{ }^{14} \mathrm{C}\right]$ glucose are illustrated in Fig. 3. These data 

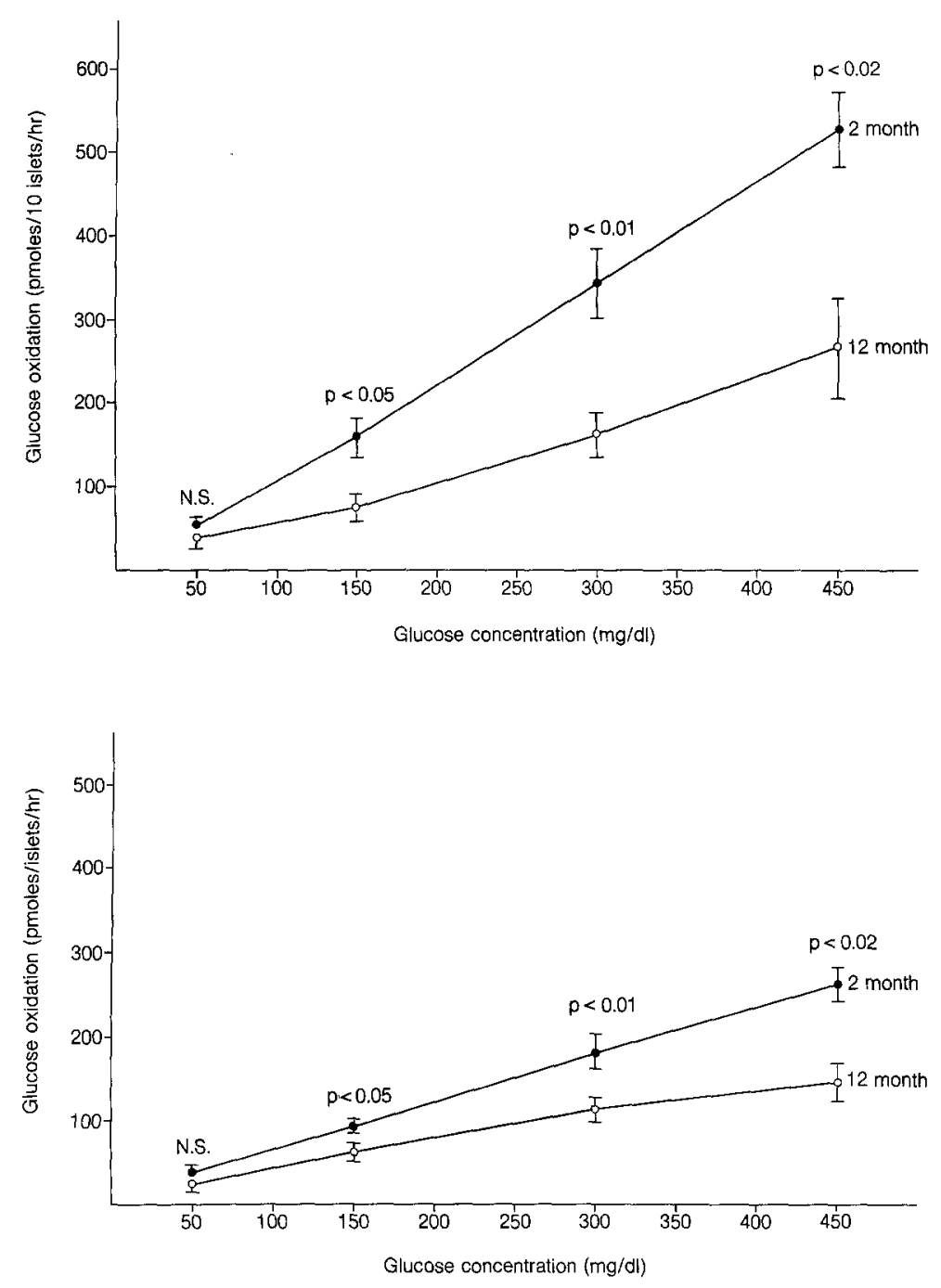

Fig. 1. D- $\left[\mathrm{U}-{ }^{14} \mathrm{C}\right]$ glucose oxidation by islets from pancreases of 2-month and 12-month-old rats isolated by hand-picking. Results are expressed as mean \pm SEM of five islet preparations from each age group at each glucose concentration
Fig. 2. D- $\left[\mathrm{U}-{ }^{14} \mathrm{C}\right]$ glucose oxidation by islets from pancreases of 2-month and 12-month-old rats isolated by Ficoll density gradient centrifugation. Results are expressed as mean \pm SEM of six islet preparations from each age group at each glucose concentration

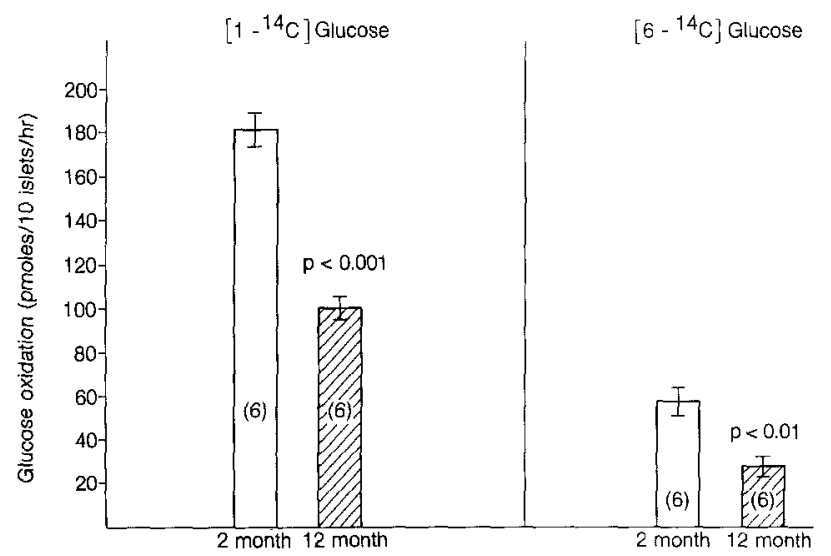

Fig. 3. Glucose oxidation by islets from pancrease's of 2 -month and 12 -month-old rats using $300 \mathrm{mg} / \mathrm{dl}\left[1-{ }^{14} \mathrm{C}\right]$ glucose or $\left[6-{ }^{14} \mathrm{C}\right]$ glucose as the radioactive tracer. The islets were prepared by Ficoll density gradient centrifugation. Results are expressed as mean \pm SEM of six islet preparations demonstrate that the amount of glucose converted to $\mathrm{CO}_{2}$ by islets from 12 -month-old rats was only half that of 2 -month-old rats, whether $\left[6-{ }^{14} \mathrm{C}\right]$ glucose or $\left[1-{ }^{14} \mathrm{C}\right]$ glucose was used (Fig. 3). In addition, Fig. 3 shows that more labelled $\mathrm{CO}_{2}$ was found when islets from rats of either age were incubated with $\left[1-{ }^{14} \mathrm{C}\right]$ glucose as compared to $\left[6-{ }^{14} \mathrm{C}\right]$ glucose. The ratio of $\left[1-{ }^{14} \mathrm{C}\right]$ glucose oxidized to $\left[6-{ }^{14} \mathrm{C}\right]$ glucose oxidized was 3.1 and 3.6, respectively, for islets from 2-month and 12-month-old rats.

\section{Discussion}

These experiments were undertaken to see if agerelated changes in glucose catabolism could account for our earlier observation that glucose-stimulated insulin secretion from isolated islets decreased as rats 
age from 2 to 18 months [1]. In order for this to be the case, several conditions must be met. In the first place, there must be a decrease in the rate of glucose conversion to $\mathrm{CO}_{2}$ as a function of age. The results seen in Figs. 1-3 indicate that this was the case. Glucose oxidation by isolated islets from 12-month-old rats was less than that of islets from 2-month-old rats, and this observation was independent of the glucose isotope used.

A second major criterion is that the observed changes in glucose oxidation must be a function of the behaviour of the endocrine, as distinguished from the exocrine pancreas. In an effort to control for this variable, we determined glucose oxidation in both hand-picked and Ficoll-separated islets. Ficoll separation was employed in an effort to minimize contamination of isolated islets with acinar tissue, and its use led to an overall reduction in rate of glucose oxidation by islets from rats of both ages. This difference could be due to the fact that Ficoll separation provides a cleaner preparation, or alternatively, to the possibility that the additional step leads to deterioration of islet function. In either event, the persistence of the age-related decrease in glucose oxidation, regardless of the method of islet preparation, suggests that the observed difference was due to a change in islet function.

Thirdly, in order to relate age-associated changes in glucose-stimulated insulin release to parallel changes in glucose oxidation it is essential that beta cells comprise most of the islet volume, and that the proportion of beta cells does not change as rats age. Previous studies from our laboratory using morphometric techniques, have indicated that both of these conditions are met [1]. These determinations demonstrated that $86-88 \%$ of the volume of both intact and isolated islets was due to beta cell volume, and that this value does not change in rats aged from 2-18 months. Furthermore, data from the same study indicated that the "average" isolated islet from a 12-month-old rat contained approximately $50 \%$ more beta cells than did the "average" islet from a 2 -month-old rat. Thus, measurements of glucose oxidation by isolated islets would seem to reflect primarily the metabolic activity of beta cells, and the number of beta cells increases with age. As a result, if the current data were expressed as glucose oxidation per beta cell the difference between 2-month-old and 12 -month-old rats would be even greater.

The above considerations are all consistent with the notion that a defect in beta cell glucose catabolism may play a role in the development of the previously described age-related decrease in glucosestimulated insulin release [1]. On the other hand, the relationship between beta cell glucose metabolism and glucose-stimulated insulin secretion remains speculative [7]. Indeed, it is possible that the observed age-related decline in glucose conversion to $\mathrm{CO}_{2}$ may have no causal relationship to the associated decrease in glucose-stimulated secretion, but simply be a reflection of decreased glucose oxidation as a function of age. In this regard, the results with $\left[1-{ }^{14} \mathrm{C}\right]$ and $\left[6-{ }^{14} \mathrm{C}\right]$ glucose provide some clue as to the site of the age-related defect in glucose oxidation. The ratio of $\left[1-{ }^{14} \mathrm{C}\right]$ glucose oxidized to $\left[6-{ }^{14} \mathrm{C}\right]$ glucose oxidized was similar in both groups of rats, and comparable to results previously published $[5,6]$. The observation that age resulted in decreased glucose oxidation with either glucose isotope suggests either a defect in glucose transport and/or phosphorylation, or decreased glucose oxidation via both the pentose phosphate shunt and the TCA cycle. Current efforts are aimed at distinguishing between these possibilities.

Acknowledgements. The authors would like to acknowledge the excellent technical assistance of Mrs. Helen Chang. The work was supported by funds from the Research Services of the Veterans Administration and by support from the Commonwealth Fund through the ASHUM Program, University of Chicago.

\section{References}

1. Reaven E, Gold G, Reaven G (In press) Effect of age on glucose-stimulated insulin release by the $\beta$ cell of the rat. $\mathrm{J}$ Clin Invest

2. Lacy PE, Kostianovsky M (1967) Method for the isolation of intact islets of Langerhans from the rat pancreas. Diabetes 16: 35-39

3. Rodbell M (1964) Metabolism of isolated fat cells. I. Effects of hormones on glucose metabolism and lipolysis. $\mathrm{J}$ Biol Chem 239: $375-380$

4. Cole EH, Logothetopoulos J (1974) Glucose oxidation and insulin secretion by pancreatic islets isolated from hyperglycemic and normoglycemic rats. Diabetes 23: 469-473

5. Ammon HPT, Verspohl E (1976) Pyridine nucleotides in pancreatic islets during inhibition of insulin release by exogenous insulin. Endocrinology 99: 1469-1476

6. Akhtar MS, Phil M, Verspohl E, Hegner D, Ammon HPT (1977) 6-phosphogluconate/glucose-6-phosphate ratio in rat pancreatic islets during inhibition of insulin release by exogenous insulin. Diabetes 26: 857-863

7. Zawalich WS (1979) Intermediary metabolism and insulin secretion from isolated rat islets of Langerhans. Diabetes 28: $252-260$

Received: April 17, 1979,

and in revised form: August 8, 1979

Gerald M. Reaven, M. D

Veterans Administration Medical Center (182B)

3801 Miranda Avenue

Palo Alto, CA 94304

USA 